\title{
Carne Argentina: las representaciones de la crisis de 2001 en la historieta
}

MHCJ no 7 | Año 2016

Artículo no 6 (78)

Páginas 139 a 168

mhjournal.org

\author{
Dr. Sebastian Horacio Gago | shgago@gmail.com \\ Universidad Nacional de Córdoba
}

Palabras clave

Historieta; Crisis; Realismo; Argentina; Sentido.

Sumario

1. Introducción. 2. Metodología 3. Resultados 4. Discusión 5. Conclusión 6. Bibliografía 7. Apéndice de imágenes 8. Notas

\section{Resumen}

Carne Argentina es la más simple y explícita obra historietística que representa los hechos del estallido económico, social y político ocurrido a finales de 2001 en el país sudamericano al que su título hace referencia. No es una historieta en rigor, sino un conjunto de siete relatos breves y autoconclusivos que presentan en un tono testimonial historias particulares de personajes comunes desarrolladas durante los turbulentos días que tuvieron como hecho político sobresaliente la sucesión de cinco presidentes de la Nación en trece días. Por haber sido realizada durante la crisis argentina misma y en un momento de crisis y renovación del ámbito de la producción y la edición de historietas en aquel país, Carne Argentina constituye un exponente de la historieta realista contemporánea. Poblada de temas, situaciones, personajes y diálogos pensados al calor de la acción, este libro, editado en 2002 en España y luego en 2003 por el sello argentino La Productora, admite de manera explícita en sus relatos las tensiones sociales contemporáneas a su creación. Nuestro objetivo será estudiar el papel clave del realismo en la construcción de mundos sociales ficcionales, y la utilización en la historieta de ciertas estrategias narrativas como artefacto interpretativo de lo real social, por fuera de los géneros narrativos dominantes.

\section{Forma de citar este artículo en las bibliografías}

Dr. Sebastian Horacio Gago (2016): “Carne Argentina: las representaciones de la crisis de 2001 en la historieta”, en Miguel Hernández Communication Journal, nº7, páginas 139 a 168. Universidad Miguel Hernández, UMH (ElcheAlicante). Recuperado el de de 20__ de: link del artículo en mhjournal.org] 


\section{Carne Argentina : representations of the 2001 crisis in Cartoon}

MHCJ no 7 | Año 2016

Artículo no 6 (78)

Páginas 139 a 168

mhjournal.org

\author{
Dr. Sebastian Horacio Gago | shgago@gmail.com \\ Universidad Nacional de Córdoba
}

Keywords

Comic; Crisis; Realism; Argentina; Meaning.

Summary

1. Introduction 2. Methodology 3. Results 4. Discussion 5. Conclusion 6. Bibliography 7. Appendix image 8. Notes

\section{Abstract}

Carne Argentina is a realistic comic that represents the facts of the Argentine Great Depression in 2001. Strictly speaking it is not a comic, but a set of seven short tales that presents pieces of personal stories of common people in the midst of the social and political crisis.

Because it has been made during the turbulent period in Argentina's history and during a crisis period of the field of the Argentine comics, Carne Argentinais an exponent of this genre.

The book contains topics, situations, characters and dialogues created on the fly, and it was published in Spain in 2002 and then in Argentina a year later by the publisher La Productora. Its episodes reveal the social conflict expressly and its greatest virtue was to have appeared fairly close to the same time period. This paper analyzes the role of realism in the construction of fictional social worlds, in addition to the use of narrative strategies as an interpretive tool of the reality, outside the dominant narrative genres.

\section{How to cite this paper in bibliographies}

Dr. Sebastian Horacio Gago (2016): "Carne Argentina: las representaciones de la crisis de 2001 en la historieta”, en Miguel Hernández Communication Journal, nº7, páginas 139 a 168. Universidad Miguel Hernández, UMH (ElcheAlicante). Recuperado el de de 20__ de: [link del artículo en mhjournal.org] 


\section{Introducción}

Acerca de la historieta argentina contemporánea

En los años noventa, se cristaliza una crisis sin retorno de la industria editorial de historietas en la Argentina, surgida a comienzos del siglo XX. El neoliberalismo económico, la convertibilidad cambiaria, la apertura económica que redundó en un aluvión de importaciones, entre ellas, contamos la irrupción de comics de superhéroes en kioscos argentinos, sumado a los malos manejos empresarios, formaron un cóctel que desembocó en la desaparición de las principales editoriales a lo largo de esa década: Puertitas, Récord, Ediciones de La Urraca y, finalmente en 2001, Editorial Columba, que fuera la más longeva y exitosa editorial de "historietas realistas" del país sudamericano ${ }^{1}$

En medio de esta crisis, entre finales de los noventa y comienzos de la década siguiente, la movida fanzinera y los pequeños sellos independientes comenzarían a marcar presencia en los eventos de historietas tales como convenciones, festivales, exposiciones, u homenajes, lo que supondría toda una novedad de esta nueva etapa del campo de la historieta argentina. Por citar un ejemplo, la editorial cordobesa Llantodemudo, con 20 años de trayectoria, se ha tornado un paradigma de un método de trabajo autogestionado, sentando influencia en proyectos posteriores (Vigna, 2015)².

La actualidad de la historieta argentina, una contemporaneidad cuyo inicio podemos situar a finales de los años noventa, cuando se consuma el quiebre de la industria editorial del medio, presenta un nuevo contexto de producción en el que creció la posibilidad de libertad creativa relativamente independiente dentro de la oferta de bienes simbólicos (Bourdieu, 2010: 88-89). Habían desaparecido las restricciones que antes imponían las editoriales comerciales del período industrial de la historieta argentina, que se extendió por casi todo el siglo $\mathrm{XX}^{3}$.

¿Cómo explicar el surgimiento de historietas que cuentan lo cotidiano, algunas de ellas acercándose al registro autobiográfico? Grafismo realista, hechos narrados presentados como pretendidamente reales, incluso manteniendo un carácter documentalista, aunque no ya desde el clásico relato de aventuras sino desde la lógica del relato del fragmento de la vida cotidiana. Se trataría de una ficción que no termina de asumir su carácter ficcional. Si las narrativas gráficas suelen contener influencias estilísticas y genéricas propias de la narrativa literaria, la historieta argentina contemporánea no es la excepción. Al respecto, Josefina Ludmer (2006) piensa cómo una moda o fenómeno de época de la literatura contamina otras esferas de bienes simbólicos: nos referimos a la "realidad-ficción" de las literaturas actuales, denominadas por la autora "literaturas post-autónomas".

Todo es ficción y todo es realidad: el nuevo régimen cambia el estatuto de la ficción y la noción misma de realidad en literatura, que deja de ser meramente una "realidad histórica" y se hace puro presente y pura "realidad cotidiana": una categoría capitalista y tecnológica. (...) La literatura absorbe la mimesis del pasado para fabricar presente y realidad en la era de los medios y de la industria de la 
lengua. Así leo hoy las escrituras latinoamericanas postautónomas: como "fábricas de realidad". (Ludmer, ob. cit.: 1)

Con su noción de "fábricas de realidad", Ludmer echa luz sobre una diferencia crucial entre la narración clásica y la narración actual. La narrativa clásica o canónica -señala Ludmer, poniendo como ejemplo a Cien años de soledad, de Gabriel García Márquez, y a la novela histórica La revolución es un sueño eterno, de Andrés Rivera, entre otras-, trazaba fronteras nítidas entre lo histórico como "real" y lo "literario" como símbolo, fábula o mito. Es decir, lo ficcional era la realidad histórica [política y social] pasada o formateada por un mito o un símbolo: El Eternauta de Oesterheld y Solano López, como metáfora de un país arrasado, podría ser un ejemplo sacado del panteón de la historieta argentina. Esa clara frontera entre la pura subjetividad y la pura realidad histórica, se ha desdibujado en la era de las "escrituras 'sin metáfora”" que, según la autora:

Serían la realidad cotidiana del presente de algunos sujetos en una isla urbana (un territorio local). Formarían parte de la fábrica de presente que es la imaginación pública (...) para contar algunas vidas cotidianas en alguna isla urbana latinoamericana. (Ludmer, 2006: 1)

La semejanza estilística entre la literatura y una porción significativa de la historieta actual, puede sintetizarse en la idea de Ludmer de que no admiten lecturas literarias o, agregamos nosotros, en clave de ficción: "['ante' la imagen como ley] todo es 'realidad' y ésa es una de sus políticas" (ibíd.). En otras palabras: no se sabe o no importa si son o no son literatura, como tampoco se sabe ni importa si son realidad o ficción (Ludmer, citado por Vigna, 2014b: 14). No obstante, a las literaturas postautónomas como prácticas literarias territoriales de lo cotidiano, no se las puede leer como mero "realismo", en relaciones referenciales o verosimilizantes (Ibíd.). Adquieren la forma de escrituras de lo real: testimonio, crónica, autobiografía, diario íntimo, etnografía. "No se sabe si los personajes son reales o no, si la historia ocurrió o no, si los textos son ensayos o novelas o biografías o grabaciones o diarios" (Ludmer, ob. cit.: 1).

En sintonía con lo que Ludmer observa en la literatura, Reggiani (2012b: 106) señala al fenómeno cultural denominado "giro subjetivo" y la exaltación del "yo" como clave para entender el surgimiento de esta nueva forma de narrar que predomina en la historieta argentina realista o de aventuras $^{4}$, y que se suma al otro factor ya mencionado: la mayor autonomía relativa del ámbito de producción de historieta frente al campo económico, "fenómeno que habilitó la producción por fuera de los géneros dominantes en los medios de masas y, sobre todo, permitió construir una figura de autor" (Reggiani, 2012b: 106). La autogestión productiva y editorial permitió la ampliación del espacio de lo decible (Reggiani, 2012a: 87-88), entendiendo por ello el universo de temas y tópicos a tratar, a saber: el quiebre de los géneros, presencia del sexo, violencia política, detalles de la vida cotidiana, la política contemporánea y el yo autobiográfico (Ibíd.). 
La nueva generación de autores, quienes actualmente rondan entre 40 y 45 años, dedicados en cierta época a escribir y/o a dibujar lo que querían y donde quisieran, sin limitaciones de ningún tipo y sin retribución monetaria alguna, no iba a durar mucho tiempo en ese estado de amplia autonomía (von Sprecher, 2009). Con el tiempo se fueron profesionalizando, para poder vivir de lo que hacen: trabajan principalmente para el exterior, adecuándose a los requerimientos de editoriales europeas y norteamericanas, o producen para el mercado argentino pero sin dejar de contemplar la posible colocación de la obra en el extranjero o una reedición en libro en el circuito local, como sucede con muchas series publicadas en Fierro. Ciertos elementos que podemos rastrear en nuestro caso de estudio, sobresalen en esas condiciones de producción nacidas en el contexto de la crisis de la historieta y de la sociedad argentina.

Un dato interesante es cómo esa relativa autonomía creativa fue promovida por nuevas condiciones técnicas de producción. Con el declive de la movida fanzinera que floreció entre fines de los noventa y comienzos de los 2000, y la llegada de la Internet 2.0 a la Argentina, sobrevendrá la publicación de historietas en Internet, un fenómeno que ya comenzaba a proliferar en el ámbito literario y que trascendió todos los géneros discursivos, cuestión que es abordada en detalle por Diego Vigna (2014a). En materia de blogs de historieta, el principal exponente argentino ha sido Historietas Reales ${ }^{5}$, plataforma online creada en 2005, cuya lógica de publicación es la tira autobiográfica semanal. Esa frecuencia de aparición genera en los autores la necesidad de producir continuadamente, y permite la interacción entre autores y lectores, muchos de los cuales son otros autores, generando un espacio de reflexión en el campo.

En este contexto actual del campo de la historieta nacional, marcado por un ensanchamiento de los límites de posibilidades de representación de la realidad -del pasado y del presente-, es donde se inserta la obra de narrativa gráfica que es objeto de nuestro estudio: Carne Argentina, editada por el colectivo independiente La Productora, primero en España (2002) y un año después (2003), en Argentina. Si hacemos un breve repaso de la historieta local de décadas anteriores, en el último cuarto del siglo XX, podremos ubicar la pieza en un todo coherente.

Desde los años setenta, desde distintos lenguajes narrativos -la literatura en prosa, el cine, la historieta- se han hecho intentos de representación de los climas tanto como de los sucesos efectivamente ocurridos en la historia política argentina. Un capítulo aparte merecen las historietas en cuyas narraciones se han representado los hechos de la última dictadura, intentos "definidos no sólo por la exterioridad política, sino por estrategias retóricas que sólo en parte pueden ser consecuencia de esa exterioridad" (Reggiani, 2012a: 86). Desde la alusión y la alegoría utilizadas en las producciones "contemporáneas a la dictadura", pasando por las referencias más directas al pasado en las historietas publicadas durante los años de la transición democrática y la "continuidad democrática" entre los ochenta y los noventa en la Argentina, llegamos a la etapa abierta en 2003, que coincide con el ascenso al poder del kirchnerismo.

En el presente período post crisis del 2001, "se actualiza al máximo la visibilidad de la acción represiva durante la dictadura y la representación de esos hechos se propone como expresa 
política de Estado" (Ibíd.). Un exponente del presente período es la actual revista Fierro, donde el terrorismo dictatorial y diversos aspectos de la historia del peronismo ha sido tema de numerosas series. Encontramos un ejemplo de la nueva tendencia de construcción narrativa en Veinte Verdades (Max Aguirre, 2011) ${ }^{6}$, una serie de episodios unitarios cuyo personaje protagonista es un joven e iluso militante peronista que vive $-\mathrm{y}$ sufre en carne propia- los chanchullos y vaivenes de la política argentina en los años noventa. En cada relato, titulado con una de las veinte máximas del justicialismo, hay una reflexión crítica sobre la identidad peronista, en tiempos de pulverización de los grandes relatos y de hegemonía de la ideología antiideológica del neoliberalismo, cuya expresión nacional fue el menemismo ${ }^{7}$.

En Carne Argentina, la narración no construye una representación de los hechos del pasado sino más bien de sucesos de un presente por entonces inmediato. De manera simple y rotunda, la obra nos habla del estallido económico, social y político ocurrido en el país austral de Sudamérica en las semanas finales del 2001, que traería emparejada una situación de inestabilidad durante los años subsiguientes. No es una historieta en rigor, sino un conjunto de siete relatos breves y autoconclusivos que presentan en un tono testimonial historias particulares de personajes comunes desarrolladas durante los turbulentos días que tuvieron como hecho político sobresaliente la sucesión de cinco presidentes de la Nación en trece días.

Pareciera que los autores del libro se formularon e intentaron responder las siguientes preguntas a la hora de sentarse a escribir y dibujar: ¿De qué manera la crisis del modelo neoliberal instalado por la dictadura y vigente con variantes en la actualidad, estalla con efectos diversos en la vida de los habitantes de Argentina? ¿Cómo contar a un lector los modos y dificultades con los que las clases populares resuelven la supervivencia cotidiana cuando un "crack" económico las empuja a resbalar y caer aún del peldaño más bajo de la escalera de la desigualdad social? ¿Qué sucede cuando la agudización de la ruptura del lazo social transparenta y desenmascara las habituales relaciones de lucha y explotación entre las clases que componen una sociedad capitalista de una nación del denominado Tercer Mundo?

Por haber sido realizada durante la crisis argentina misma y en un momento de cambio y renovación del ámbito de la producción y la edición de historietas en el país, Carne Argentina constituye un exponente de la historieta realista contemporánea. Poblada de temas, situaciones, personajes y diálogos pensados al calor de la acción, este libro, editado en 2002 en España y luego en 2003 por el sello argentino La Productora, admite de manera explícita en sus relatos las tensiones sociales contemporáneas a su creación. Nuestro objetivo será estudiar el papel clave del realismo en la construcción de mundos sociales ficcionales, y la utilización en la historieta de ciertas estrategias narrativas como artefacto interpretativo de lo real social, por fuera de los géneros narrativos dominantes.

El objetivo de este trabajo es leer qué hacen los autores con esa libertad originada en la post crisis y desaparición del esquema industrial del campo de la historieta argentina, y cómo construyen, en 
medio de los acontecimientos, crudos relatos de "realidadficción" (Ludmer, ob.cit.) que, rompiendo las barreras genéricas, nos hablan del presente.

\section{Metodología}

Nuestra perspectiva metodológica, que se nutre del marco teórico, es fundamentalmente sociológica (Bourdieu, 1988, 1995; Martín-Barbero, 1988; Williams, 1981). A partir de este enfoque, estudiamos los trabajos de los autores en relación con una serie de condiciones contextuales, entre ellas, las otras posiciones del campo historietístico ocupadas por editoriales y otros autores, el origen social de los creadores, y las relaciones y condicionamientos de sus respectivas actividades respecto del campo económico/empresarial, el mundo político y el ámbito cultural.

En este trabajo abordamos a las historietas como discursos, es decir, como producciones de sentido, materializadas, construidas desde y constructoras de lo social. Las historietas contienen huellas de los procesos y condiciones de producción de ese sentido. Como señala Verón (1993), a través de los productos, de las marcas que en ellos encontramos, podemos reconstruir, al menos fragmentariamente, los procesos que han determinado las formas en que entendemos al mundo, las "representaciones sociales". Por sentido entendemos los modelos de/sobre realidad que se construyen y ponen en circulación en los distintos tipos de discursos, entre ellos en la recepción cultural (Verón, 1993). Dar sentido a algo, a alguna cuestión, implica incluirla en una historia o una tradición, organizarla a través de un significante (Nicastro, 2006: 57).

Pensar a las historietas como discursos nos habilita a considerar el nivel de lo ideológico. El texto, cuando refracta, representa o sustituye algo que está "fuera" de sí, explicita una operación ideológica, pone en juego valores que residen en el colectivo social con el que interacciona (Voloshinov, 1992: 32). Voloshinov y Bajtin señalan que el sentido se construye dinámicamente, pues el texto nunca está cerrado, en él están presentes múltiples voces, se construye un tejido de textos con los que éste dialoga. La historieta de aventuras, como discurso y lenguaje, nos permite revisar diferentes aspectos que atañen a sus posibles interpretaciones, socialmente determinadas, a las relaciones dialógicas de la obra con otro/s texto/s y al posicionamiento del artista respecto a su trabajo y a su propio rol dentro de determinado campo.

No entendemos lo ideológico como un problema de falsa conciencia o de ocultamiento de la realidad, sino como la forma en la cual una sociedad organiza lo visible y lo no visible, lo que se puede pensar y lo que no. Esa forma de organización tiene relación con cómo se enmarcan ciertos conflictos y ciertas prácticas, y cómo se regulan y organizan las vivencias posibles de los sujetos (Cf. Zizek, 2003). Se piensa a lo ideológico como una práctica: no como una creencia que se tiene, sino que uno está en la creencia, y esa creencia se encarna en la materialidad de la vida de los sujetos. En este mismo sentido es que Hadjinicolaou (1988: 12) define a la ideología como la "expresión de la relación de los hombres con su 'mundo", y agrega: "Las sociedades humanas secretan la ideología como el elemento y la atmósfera misma indispensables para su respiración, para su vida histórica" (1988: 13). 
La pregunta que nos surge sobre nuestro objeto de análisis, la historieta Carne Argentina, a la luz de nuestro marco conceptual y metodológico, es: ¿Qué marcas nos permiten dilucidar lo ideológico subyacente en su discurso y de qué modos (sea en contenido, forma, presentación y producción) esta historieta se relaciona con lo político? Nuestro análisis se abocará a determinar algunas huellas o marcas de las relaciones que, en los últimos años, la historieta argentina ha tejido con otras zonas de la producción narrativa local y mundial, y con la realidad política y social. La impronta genérica de "realidadficción" de la obra, nos sirve para pensar en estas relaciones.

\section{Resultados}

\section{1. Análisis}

Intentaremos en lo que sigue enfocarnos en establecer relaciones entre el discurso historietístico y las marcas o pliegues de la exterioridad social y política perceptibles o detectables en la materia significante.

Debajo del prólogo de Carne Argentina, un breve texto aclara el contenido: "Las historias que siguen apenas son apuntes e impresiones sobre el estallido social ocurrido en Argentina a fines del año 2001. Los autores y sus personajes son, por igual, confundidos pasajeros de una nave que hace rato va sin rumbo y sin timón". Se trata de una nota aclaratoria a la edición española de la historieta hecha en mayo de 2002, cuando las esquirlas del estallido aún golpeaban. Un año y medio después saldría la versión argentina que tenemos entre manos. Debajo de su prólogo, en los créditos editoriales, un texto presente en todas las historietas publicadas por La Productora, relativiza el posible valor testimonial sin descartar el posible efecto de verosimilitud de la narración: "Todos los personajes e instituciones incluidos en estas historias son ficticios, cualquier semejanza con hechos y personas de la realidad es mera coincidencia".

Las acciones, las "historias", transcurren en la Ciudad de Buenos Aires y en el conurbano bonaerense, compuesto por una serie de distritos de alta densidad poblacional que rodean la capital argentina. El espacio geográfico es reconocible por las referencias directas a la arquitectura (nombres de calles, edificios históricos, espacios verdes, etc.), el lenguaje (la variable dialectal porteña del castellano) y el contexto social, económico y político, a saber: los personajes viven inmersos en el desempleo continuado, la precariedad laboral, la (sensación de) inseguridad, la protesta y la represión policial, la cesación de pagos, la confiscación de ahorros, la especulación financiera, la escasez y el saqueo de alimentos, y hasta el festejo de un campeonato del Racing Club; un tradicional equipo de fútbol cuya sede y estadio se sitúan precisamente en una de las ciudades más pobladas del conurbano, Avellaneda.

Los elementos enumerados nos permiten inferir que el tiempo de la acción es contemporáneo al de su realización: la crisis argentina de 2001. Pero hay otro tipo de incidíos que completan el sentido de contemporaneidad: la ropa de los personajes, el uso de computadoras, teléfonos celulares y cajeros automáticos, y la aparición, en diálogos, en el espacio público urbano y en 
remeras de personajes, de nombres propios de dirigentes políticos que tuvieron relevancia en ese momento, como el expresidente (Fernando) de la Rúa (quien aparece retratado), Elisa Carrió, Carlos Ruckauf, Eduardo Duhalde, "Mingo" Cavallo, entre otros. Esa generosidad en datos contextuales tanto del texto como de la imagen se imponen a la aparición, menos frecuente, de referencias indirectas u oblicuas, salvo cuando se trata de buscar complicidad con el lector local en el reconocimiento de particularidades de la cultura y la historia nacional.

Las referencias indirectas abren un campo de posibilidades de otro nivel de recepción, promoviendo otro tipo de goce en la experiencia lectora más allá de una interpretación lineal: otras capas de sentido son reconocibles, disfrutables, por lectores "locales", empapados en el código cultural. Veamos algunos ejemplos de esto, aclarando que en los casos citados, se perciben indicaciones temporales precisas incluso en los recuerdos de hechos pasados de los personajes, o en los comentarios directamente ligados al conflicto del momento. Nos sirven de ejemplos numerosos diálogos de cómic: En el episodio "Los devoran los de afuera"8 (Ángel Mosquito), el "Flaco", un vecino cuarentón del barrio Chorizo9 afectado por la pobreza y el paro, intenta persuadir al protagonista, "Pancho", un joven, también desempleado, para saquear un supermercado porque "ahora no hay más Cajas PAN"10 (cfr. pág. 24, viñeta 3).

El "Flaco" le sugiere a "Pancho" que vaya a pedirle a su hermano, Ariel, repositor del supermercado, que le facilite un bolsón de comida. Apela a una poco ortodoxa cita literaria para convencerlo: "Daaale, vamos, si se va a poner contento de verte el Arielcito... Es bueno siempre tener un contacto, ahora todo es por contactos. Los hermanos sean unidos, decía el General!" (cfr. Pág. 24, viñeta 8)". La frase tiene como referente a uno de los consejos del "Viejo Vizcacha" a uno de los hijos del gaucho Martín Fierro, en La Vuelta de Martín Fierro, la segunda parte de la reconocida obra de José Hernández ${ }^{11}$. La atribución de la frase al General (claramente, se refiere a Perón), nos da una imagen del saber popular, ese folclore en términos gramscianos, que habita en el sentido común de las clases populares argentinas.

La siguiente intervención verbal del "Flaco", termina de darnos una idea de más acabada de cuál es su identidad política, impregnada por la creencia y la nostalgia en el peronismo como un movimiento político que promueve la alianza de clases sociales y la progresiva inclusión de los sectores menos favorecidos en la participación de la distribución de la riqueza: "Acá lo que pasa es que tiene que volver Perón... si no se va a armar una, loco...”. A la fecha del levantamiento social del 2001, el General Perón llevaba 27 años de muerto.

Ariel, el hermano de Pancho que trabaja en el supermercado, continuamente suele recriminarle a éste: "No laburás porque no querés ¡iYo sí que pongo el lomo en esta casa!!” (cfr. pág. 23, viñeta 4). La intervención representa el racismo de clase extendido en buena parte de la sociedad argentina, construcción ideológica que construye a la pobreza como una situación de otros y no propia, situando al pobre y al desempleado en el lugar del vago, del que prefiere no trabajar, disposición que lo hace responsable de su destino. Los mismos prejuicios encontramos en los 
diálogos entre Ariel y un compañero de trabajo, en medio de retrasos salariales, amenazas de despidos, protestas y un inminente saqueo:

- Ayer leí en el Crónica12 que habían saqueado un supermercado en Rosario...

- Ja, ni gatos les deben quedar para morfar ${ }^{13} \ldots$ acá ni creo que llegue esa... si a los negros les tirás un hueso y se calman... (cfr. pág. 22, viñetas 1 y 2 )

En otro intercambio entre Ariel y su colega, se reitera el prejuicio social:

- ¿Vos decís que nos pagan?

- ... Gracias que no nos echen...

- Si llego a perder el laburo por esos negros de mierda ${ }^{14}$ de ahí afuera, salgo con una escopeta a matarlos a todos.

- Ja ja... „iRambo!! Si esos tipos entran no te van a quedar ganas ni de cagar sentado. (cfr. pág. 26, viñetas 1, 2 y 3).

Los diálogos contienen referencias a la cultura nacional que funcionan como guiños de complicidad al conocimiento del lector argentino, quien reconocerá una mayor cantidad de climas y temas representados, si bien podría entenderlo un lector extranjero, que no necesariamente conozca el trasfondo histórico al que se alude o que se interese por otros aspectos estéticos del relato. Otro ejemplo lo tenemos en varios pasajes de "Los colores del campeón" (Jok). "El Zurdo" y "Coco", los personajes principales del episodio, recorren un centro de compras en medio de saqueos, cacerolazos y renuncias de funcionarios, a horas del 20 de diciembre de 2001:

\footnotetext{
- "Christmas Sale". Ahora hasta decir "Navidad" es grasa ${ }^{15}$.

- Y qué querés Zurdo, la gente que viene acá..."16.

- ¿Cómo sería el Día de la Tradición en el shopping? ... ¿ “Gauch Holiday”? (cfr. pág. 8 , viñetas 5 y 6$)$
}

El oxímoron en inglés pronunciado por el "Zurdo", a quien lo llaman con ese apodo por su militancia en un partido de izquierda trotskista, ironiza sobre el devenir de ese difuso conjunto de costumbres, valores, prácticas y rituales conocido como "tradición criolla", la cual incluye el folclore musical argentino. Desde el menemismo hasta el presente -estamos escribiendo este trabajo en los días finales de 2015-, el proceso de mercantilización arrasó todos los aspectos de la vida, incluida la "tradición".

Podemos notar en Carne Argentina, cómo sus narraciones suponen un referente explícito y deliberado: la vida cotidiana de personas comunes durante la crisis argentina de 2001-2002. Esa decisión narrativa tiene relación con el momento de su producción, que hemos caracterizado como un período de la historieta local marcado por el ensanchamiento sin precedentes del espacio de lo decible, que viene de la mano de una tendencia desarrollada en el escenario más 
amplio de la narrativa y que Ludmer (2006) define como un tipo de escritura actual, de la realidad cotidiana, que pretende ser leída menos como un documento que como un sentimiento sobre lo real. Una historieta testimonial o el comic periodístico al estilo de Joe Sacco, no hubiera surtido el efecto estético que tienen estos relatos sobre retazos de la vida cotidiana que parecen haber sido producidos por cazadores de anécdotas reales que no están preocupados tanto por dar visos de realidad o de ficción a sus discursos, pues a veces el sentido literal de los acontecimientos es insuficiente para narrar la Historia (Berone, 2014: 22).

El anclaje de textos e imágenes en un real histórico se refuerza con la identificación detallada de los personajes centrales. Cada historia está precedida por un paratexto inusual en un libro de historietas: se trata de un "perfil" que describe a cada protagonista con nombre y apellido, edad, género, ocupación, domicilio y filiación política. La "ficha personal" ayuda al lector a imaginar o proyectar las posibles acciones del personaje, que serán siempre sujetos del montón. Además de esta ficha, un breve epílogo en prosa, al final del libro, compendia las trayectorias post crisis de los protagonistas de cada unitario, verificándose pocos cambios en términos de movilidad social, sobre todo en los personajes de clases bajas. En ese epílogo, las huellas del nuevo contexto político, económico y social abierto con el kirchnerismo, están presentes: por ejemplo, "el gerente del banco es ahora un prominente banquero K y visita a menudo la casa de sus raptores".

Volvamos a la "ficha personal" que precede a cada relato. De entrada, se ofrecen signos que refuerzan la identidad de los personajes como gente común, y que nos sugieren una respuesta a la pregunta: Dadas ciertas condiciones previas de existencia, ¿qué pasa con los sujetos cuando sobreviene la crisis? Como caso de ejemplo, analizaremos el episodio "Los inadaptados de siempre" (Cristian Mallea y Aón). El tópico de la guerra de clases está presente, como en la mayoría de los capítulos del libro. La protagonista es una joven de poco más de 20 años. El "perfil" nos indica que tiene un novio, trabaja como empleada y estudia en la universidad, y además "odia la política".

El relato desliza una crítica ideológica a los medios de comunicación masiva, en particular la televisión, por su papel como constructores de esquemas de percepción y valoración sobre personas y grupos, influyendo en las relaciones sociales y en las posibilidades de convivencia. Por caso, los discursos de los medios criminalizan la pobreza al transmitir prejuicios sociales y racistas que impregnan el sentido común del ciudadano medio. En "Los inadaptados de siempre" podemos advertir cómo la mediatización de la experiencia social (Boito, 2014) hace el campo orégano al enfrentamiento entre habitantes de dos barrios aledaños que temen por lo mismo: que los que viven en la barriada vecina vayan a despojarlos de lo poco que tienen. La referencia a la realidad argentina es ineludible, pues en aquél país los saqueos se han convertido en una experiencia que forma parte del imaginario social. Y la representación del "otro" a partir del discurso mediático, sin la posibilidad de construcción de una relación social in-mediata, genera el desconocimiento y el miedo entre pobladores de una misma zona de la ciudad. El diálogo entre padre e hija (Andrea) grafica la situación: 
- ¿Qué es ese quilombo en la equina, papá?

- Nena, ¿vos no escuchás el informativo? Dicen que esta noche van a salir a saquear las casas.

- Ay, papá. ¿Y vos le creés a los periodistas?

- Andá a ver a tu hermana, por favor.

Voz del periodista que sale en la pantalla televisiva: "Esta noche los mismos inadaptados de siempre...” (cfr. pág. 39, viñetas 3 y 4).

El padre de la protagonista le ordena que vaya a consolar a su hermana, María, quien llora en su cuarto creyendo lo que le ha anunciado su progenitor: "que los de barrio Matera van a venir a saquear Loma Grande", situado en el partido de Merlo, en el Gran Buenos Aires ${ }^{17}$. Resulta que Juan, el novio de María, vive en barrio Matera, y ella teme lo peor: un enfrentamiento entre vecinos de barrios aledaños que pudiera derivar en una tragedia, justo cuando cumplen su aniversario de novios. La situación guarda una vaga conexión con el episodio mitológico del rapto de las sabinas: en este caso, una mujer sufre por el posible enfrentamiento entre su novio y sus familiares consanguíneos.

Las calles de Loma Grande son ganadas por los rumores que dan por seguro el ataque de los pobladores de la barriada cercana. Los vecinos, no sin prejuicios sociales y racistas que llegan hasta la animalización del "otro", montan guardia durante toda la noche, con un variado combo de armas (pistolas "tumberas", machetes y palos) para repeler a los supuestos saqueadores. Finalmente, no hay saqueo alguno. Juan, el novio de María, llega en un vehículo con un oso de peluche como prenda de amor a su prometida. Se salva de ser alcanzado por un balazo de los pertrechados, que da en la cabeza del osito. Tras el incidente, el joven cuestiona a los vecinos de Loma Grande: “¿Ustedes también con esa mierda? En mi barrio todo el mundo está armado esperando que ustedes los vayan a saquear". (cfr. pág. 44, viñetas 3 y 4).

Otro episodio en el que se representa el conflicto de clases, o al interior de un mismo sector social, es "Los devoran los de afuera", de Mosquito, al que ya nos hemos referido. En el rubro filiación política, el protagonista es definido así: "Ninguna. Su padre era peronista", dato que nos sugiere que, ante el desastre social, económico e institucional en que se vio sumergida la Argentina, sobreviene la crisis de representación de la política tradicional, viniendo asimismo aparejada la crisis de las identidades partidarias. La descripción de "El Pancho"guarda continuidad, pese a la distancia temporal, con aquella candorosa frase que Leonardo Favio puso en boca de Gatica, ElMono"18: "Yo de política no entiendo nada, yo soy peronista".

Volvamos a la descripción inicial del episodio, que comenzamos anteriormente (pp. 6 y 7): "El Pancho" es un joven desocupado de origen humilde, que para llevar comida a su casa y conseguir que "la vieja" -su madre- no sucumba del hambre y pueda "pasar una buena Navidad", decide saquear un supermercado, justo donde su hermano Ariel trabaja como repositor. A éste se le adeuda el salario y lo tienen al borde del despido, y para colmo de males, su patrón le pide que 
defienda a la empresa ante un eventual ataque de la "gente que está afuera". El conflicto de clases, aún entre los sectores sociales bajos, es el motivo central del relato.

En toda historieta, un lenguaje híbrido, la historia no es sólo texto (Reggiani, 2012a). Numerosos elementos que permiten situar la acción son gráficos, no verbales, opciones que parecen ser tanto de tipo estilístico como temático. Cobra importancia no sólo lo que se dice y se muestra, sino además el modo de decirlo. El grafismo de este unitario de Carne Argentina, poblado de momentos de claridad en la representación, incluye también la ambigüedad. Veamos un ejemplo.

Uno de los personajes secundarios de "Los devoran los de afuera", es una puntera política de físico robusto y pelo rubio a quien "Pancho" la identifica como "La Gorda Carrió". Sabemos su verdadero nombre -"Lita", no "Lilita", el apodo de la dirigente política Elisa Carrió- por un activista que la conoce como conductora de una Unidad Básica19. "Lita" lidera un grupo de individuos que bloquean el acceso al supermercado Coto en reclamo de alimentos. El personaje, sin embargo, es insistentemente apelado por "el Pancho" por el sustantivo común "La Gorda” y el nombre propio "Carrió".

Aquí la precisión referencial es doble, tanto por lo verbal como por la elección gráfica: el nombre y los rasgos físicos del personaje remiten a Elisa Carrió. Sería una suerte de "nombre propio gráfico" (Reggiani, 2012a), una figura reconocible inmediatamente por cualquier lector argentino de mediana edad. No obstante, su uso es irónico, pues es difícil imaginarse a la Elisa Carrió real, dirigente de una fuerza política de derechas liderada por el actual presidente de Argentina, Mauricio Macri, apostada frente a la puerta de una multinacional pidiendo alimentos para los más afectados por la crisis, tal como lo hace el personaje (cierto es que en 2002, Carrió, recién desprendida del tradicional partido Radical, no estaba por entonces posicionada políticamente en la derecha como ahora). La ironía continúa en boca de "Pancho”: “QQué organización, loco! Se vinieron con micro, gorda, todo... Yo a la Carrió la voy a votar" (cfr. pág. 25, viñetas 4 y 5 ).

El relato es sobrehistorizado: no podría ocurrir sino en un lugar y una época específica. Inclusive en la secuencia siguiente (cfr. pág. 25, viñetas 6-8), un mensaje "audiovisual” incorporado a la diégesis del relato nos acerca una información panorámica de los hechos que los contextualiza históricamente: Ariel, hermano del "Pancho", toma cuenta a través del noticiero televisivo que mira en el comedor de la empresa, de que “... tristes imágenes que se repiten en todo el Gran Buenos Aires como en 1989, los saqueos".

No obstante esta sobrehistorización, hay lugar para el uso de la alegoría o del símbolo en cuestiones que van más allá de los temas o isotopías vinculados a la crisis argentina (saqueos, represión, conflictos de clases, cerco financiero, renuncia presidencial, éxodo de argentinos, etc.). Introduciremos un par de ejemplos que tematizan uno de los tópicos principales del libro: la victoria simbólica de las clases sociales menos favorecidas por su origen y por los sucesos de la crisis, frente a los sectores más favorecidos, también por origen social y por las circunstancias de la Argentina del 2001 y 2002-. 
En el unitario "El corralito" (Federico Reggiani y Gervasio), un gerente de banco es secuestrado por un hombre recientemente despedido de su empleo, que no puede retirar su indemnización del banco causa del "corralito". "Ricardo Ponce de León" nos recuerda, por aspecto físico, profesión, hechos que se le imputan, a Domingo Cavallo, el superministro del gobierno de De la Rúa que finalizara abruptamente el 20 de diciembre de 2001, y mentor de las medidas económicas que afectaron a millones de personas y que salvaron a grandes empresas y bancos ${ }^{20}$.

La trama del episodio cuenta cómo el gerente es obligado a pasar la Navidad con la familia del parado, quien simboliza a esa clase media sumergida que entre la mitad de los noventa y comienzos del 2000 se convirtieron en los "nuevos pobres" de Argentina. Queda expuesta la hipocresía del alto funcionario bancario cuando intenta persuadir al dueño de casa para que lo libere: "Pero si yo soy un laburante como vos...", suplica al ahorrista, quien responde: "¿Vos sos un laburante? Pero déjate de joder... vos sos un ladrón". (cfr. pág. 60, viñetas 1 y 4). En el diálogo es reconocible un nexo referencial con el maquiavelismo económico del exministro Domingo Cavallo, que aseguraba en 2001 que no podía vivir con 10 mil pesos de sueldo (en esos años, ese ingreso alcanzaba y sobraba para cualquier familia argentina).

La venganza simbólica contra la clase social que se benefició a expensas de otras, se representa en la secuencia de la cena de Navidad. El gerente se ve obligado a ayudar en la cocina y a ingerir alimentos comunes de consumo popular: sidra, pan dulce, ensalada de frutas, matambre al horno y, ese mismo día por la mañana, un desayuno frugal: “¿Los gerentes de banco toman café con leche?”, pregunta la mujer del jefe de casa (cfr. pág. 58, viñeta 3). En el diálogo final entre secuestrador y secuestrado, la referencia a la coyuntura política es directa: "¿Cuándo me van a dejar ir?", pregunta el banquero. "Qué sé yo... cuando mejoren las cosas. Ahora que hay un presidente nuevo, ¿quién te dice?”21, y luego pregunta a su mujer: “¿No quedó más sidra?”. La intervención de la suegra del ahorrista -una anciana con arterioesclerosis-, remite a la valorización acerca de los políticos que prevalecía en la población argentina: "Y que le dé de comer a las gallinas... que sirva para algo" (cfr. pág. 62, viñetas 3-8).

La anulación de todas las insignias que diferencian al hombre en sociedad, el intercambio de roles sociales, implican el rebaje de lo sublime, lo espiritual, intelectual y refinado, que es llevado a una expresión material y corporal, queda plasmado en las imágenes grotescas que pueblan el episodio. Así tenemos al gerente de banco ayudando al ama de casa en la preparación de una ensalada de frutas, ingiriendo comidas y bebidas accesibles a gente empobrecida, o recibiendo la orden de una anciana demente pidiéndole que vaya a alimentar las gallinas, no son más que imágenes en las que la comicidad tiene un fuerte contenido social-popular (Loschi, 2000).

La revancha social y simbólica, unida a la humillación del otro de clase, es también tema del unitario "Uno de los pibes" (Diego Agrimbau y Dante Ginevra). Roberto, es un ingeniero que ocupa el cargo de gerente en la empresa petrolera argentina YPF22, que cae bajo las garras del "corralito". En su desesperación, visita a su vecino del country de enfrente a su casa, para 
mendigarle un dinero con el fin de hacer una "inversión" y sacar réditos con la moribunda convertibilidad monetaria. El vecino es un mediático futbolista de origen humilde, cuya fisonomía nos remite al "Apache" Carlos Tévez, ídolo deportivo, o a otro muchacho que a base de goles logró abrirse camino en la vida.

El "Bizco Fanguzzi", quien al igual que el mencionado Tévez viste la casaca del popular Boca Juniors, pide a Roberto que, a cambio del favor, lleve a su fiesta a "Silvina", su hija, una joven atractiva que se deshace por asistir al cumpleaños en la casa del "Bizco". La entrega de su "bien" más sagrado, se suma a otras concesiones que van en la línea de un grotesco rabelesiano. Rubén, amigo del anfitrión, acusa a Roberto de haber sido responsable del despido de su padre en la empresa petrolera, y le exige: "Yo quiero que, por un día, vos seas uno de nosotros. Esta noche te quedás acá conmigo" (cfr. pág. 51, viñeta 4).

El gerente de YPF, presente toda la noche, en realidad "no estuvo" en una fiesta repleta de excesos y derroche donde no falta la risa satírica a la catástrofe del "corralito" (cfr. pág. 52, viñeta 1-4). El ingeniero no pudo o no quiso disfrutar absolutamente de nada. Finalmente, recibe sólo la décima parte del dinero que había pedido al "Bizco", ante la mirada y el cuchicheo de sus vecinos pacatos de clase media que pasan frente a la casa del ídolo futbolero. El relato condensa los avatares, angustias, humillaciones y miserias provocadas por el desastre económico argentino. El diálogo final entre el futbolista y Roberto lo dice todo:

- ¿Sabés lo que pasa? Al viejo de Rubén también le dieron menos de lo que quería. Y se la tuvo que morfar. Es la ley de la vida... Che... ¿qué se dice?

- Gracias...

- No, gracia’vo.

- (entre dientes, a lo lejos): Negro de mierda. (cfr. pág. 54, viñetas 3-6)

La respuesta del "Bizco" no es sino la típica muletilla con la que un futbolista profesional promedio cierra las entrevistas periodísticas: "No, gracia' vo". La inclusión de esa frase verbal permite a un lector argentino completar su referencia fuera del mundo de ficción.

Como corolario, el insulto entre dientes y a lo lejos del ingeniero es la expresión de su resentimiento, de su lamento por la posición social y la dignidad perdidas: el grotesco inunda el episodio, y llega a su momento cumbre en las escenas del cumpleaños del "Bizco", una orgía con sexo, drogas y alcohol, y se entiende a partir de una explicación sociológica. Las diversas acciones de los personajes están ligadas a la coyuntura social, cultural, económica del momento. Los amigos del cumpleañero, de extracción humilde, están ahí porque su ídolo no olvida sus orígenes. Al igual que Carlitos Tévez cuando se reúne con sus amigos de infancia en el barrio de extracción humilde que lo vio crecer, popularmente conocido como "Fuerte Apache", y esa certeza del guión permite al relato generar un efecto de verosimilitud. 


\section{Discusión}

Cabe hacer algunas precisiones acerca de la metodología y la bibliografía empleada en esta investigación. La revisión y büsqueda bibliográfica se ba concentrado en contribuir a un avance de una linea de estudios desarrollada desde hace más de quince años por un equipo argentino de investigación fundado y dirigido por Roberto von Sprecher. Formalmente constituido en 2001, el proyecto Estudios y Crítica de la Historieta Argentina (ECHA), financiado por la Secretaría de Ciencia y Tecnología de la Universidad Nacional de Córdoba, ha contado con una línea principal de pesquisa científica desdoblada en dos sublíneas: la primera, que parte de la sociología cultural de Pierre Bourdieu, tiene como objetivo el estudio del campo actual de la historieta realista argentina, los agentes que lo integran -editores, autores, críticos, público lector- y el análisis de otros aspectos y perspectivas significativos, para su compresión, de períodos anteriores.

La segunda sublínea apunta al análisis discursivo: se propone reconstruir los modelos de orden social y de resolución de las relaciones y conflictos sociales construidos en las historietas, desde una perspectiva comparativa que tiene en cuenta las condiciones sociales de producción de las obras (von Sprecher, 2010:1). Estos trabajos han partido de la hipótesis de que las historietas presentan modelos de orden social divergentes de otros títulos contemporáneos a su creación o, siendo producidos por el mismo autor, de historietas publicadas en distintos períodos históricos de producción. Un caso es el de Héctor Germán Oesterheld quien, a lo largo de 25 años de trayectoria, ha variado significativamente en cuanto a las características de los modelos sociales construidos en sus guiones, a saber: la naturaleza grupal o individual del protagonismo, las relaciones sociales de poder establecidas entre los personajes, la profundidad psicológica de los protagonistas, y el papel del conocimiento o el saber en torno a las relaciones y los conflictos entre personajes planteados en la trama.

Es esta segunda sublínea sobre la que sostenemos el presente trabajo. Nuestro punto de partida conceptual y metodológico para el análisis de discurso de las historietas se basa en el análisis de modelos de sociedad construidos en obras literarias que realiza Bourdieu en Las Reglas del Arte (1995), complementado con la teoría y estudios de Eliseo Verón y la aplicación al análisis de las historietas de la teoría de la enunciación.

El aparato teórico-analítico de la sociosemiótica de Verón nos fue de utilidad para resolver la pregunta sobre cuáles son las posibilidades y los límites de incluir lo político en una historieta. En ese sentido, nuestro análisis de Carne Argentina se abocó a determinar las huellas o marcas de las relaciones que, en los últimos años, la historieta argentina ha tejido con otras zonas de la producción narrativa local y mundial, y con la realidad política y social. La impronta genérica de "realidadficción" de la obra, nos sirve para pensar en estas relaciones.

Esta última perspectiva examina la construcción de la instancia de enunciación ofrecida en las obras contemporáneas de narrativa gráfica. Al utilizarla, hemos ponderado el enfoque usado en este artículo con el de otros autores o análisis previos que han trabajado cuestiones relacionadas con el 
tema (Reggiani, 2010, 2012b). De los estudios de la enunciación en la historieta, nos ha interesado enfocar el análisis de los modos en que en los textos se construye una situación comunicacional, a través de dispositivos lingüísticos y no lingüísticos (Steimberg, citado en Reggiani, 2010:2), incluyendo entre los primeros a los paratextos y las marcas del enunciador gráfico. Estas marcas las observamos en la renuncia a la alegoría y a la vaguedad, mediante la inclusión, a veces explícita y otras veces mediante alusiones, de nombres propios con sus fechas correspondientes Berone y Reggiani, 2012:11), lo que implica una renuncia a una lectura universal o extranjera (ibíd.). Desde su portada y primera página, Carne Argentina contiene una carga de referencialidad y politicidad a partir de los elementos paratextuales, que asimismo sirven al establecimiento de un "contrato de lectura" que completa u orienta la escena comunicacional que el relato construye (Reggiani 2008). Eso se observa en los prólogos y notas aclaratorias que hacen las veces de filtro cultural que alivia la imposibilidad de una lectura universal de la narración.

En fin, el interés de este trabajo ha sido identificar las marcas de lo ideológico subyacente en el discurso y de qué modos (sea en contenido, forma, presentación y producción) la historieta se relaciona con lo político. En nuestro caso de estudio, se trata de un relato de aventuras que, como discurso y lenguaje, contiene relaciones dialógicas con otro/s texto/s (obras literarias, discursos y hechos políticos, discursos periodísticos, refranes y dichos populares, etc.) y sus propios autores se posicionan de determinada manera respecto a su trabajo y a su propio rol dentro de determinado campo. Al respecto, como producto típico de una etapa postindustrial del campo de la historieta argentina en la que fue posible una producción en alto grado independizada de los condicionamientos del mercado, Carne Argentina se trata de un proyecto colectivo nacido en un contexto que combinó libertad creativa y el derrumbe económico.

\section{Conclusión}

Carne Argentina es un exponente de la historieta realista contemporánea. Fue escrita en un momento en que se conjugaba una dura crisis económica, política, moral y social, y, al mismo tiempo, una fuerte renovación y recuperación del ámbito de la producción y la edición de historietas en Argentina. Varios de los autores que participaron de este libro, hoy son referentes indiscutidos de la historieta nacional, reconocidos internacionalmente, como los guionistas Diego Agrimbau y Federico Reggiani, o los autores integrales Mosquito, Cristian Mallea y Jok.

En este trabajo examinamos la manera en que la temporalidad de la acción es tematizada en la(s) trama(s) de la obra historietística. Los personajes de cada episodio, son una concentración de esa temporalidad, perceptible en cada uno de los elementos utilizados para caracterizarlos, y en particular en el lenguaje que utilizan. Los personajes no participan de la violencia porque sean naturalmente violentos, sino que son las condiciones de existencia y sus disposiciones y valores, factores que los impelen a tomar decisiones al calor de los acontecimientos.

Existe un sobrehistorización de la narración, un efecto de realidad de los acontecimientos vinculado a la perspectiva cotidiana utilizada (Cf. von Sprecher, 1996:199) y a la recreación, en la ficción, del contexto sociopolítico y sociocultural -dentro de cual se encuentran las cuestiones ideológicas- que hace parte de las condiciones de producción de la obra. La violencia entre 
vecinos del mismo barrio y de barrios diferentes, entre hermanos, entre patrones y empleados, entre ahorristas y banqueros, es una violencia que no vale por sí, sino que está politizada, subsumida en un marco más general que no la autonomiza de sus condiciones de gestación (Reggiani, 2012: 93-94).

Si la historieta argentina, a diferencia del humor gráfico, no ha sabido admitir de manera explícita en sus relatos las tensiones sociales contemporáneas a su creación (Berone, 2012:43-44), Carne Argentina va a contracorriente a esa tendencia. Señala Berone que esa tradicional "despolitización” de la historieta no es propia de los relatos en general, sino un resultado del modo de producción de las historietas que apunta al mercado exterior. La mayor autonomía respecto de lo económico ganada por el campo de producción de historieta en Argentina, entre cuyas notas distintivas se destaca la autogestión editorial, y las nuevas tendencias en el sistema de géneros en otras zonas de la narrativa, como la literatura, habilitaron, en el presente siglo, la politización del discurso del medio, la posibilidad de tematizar conflictos de la vida cotidiana.

En medio de la crisis del país, Carne Argentina sería editada primeramente en España, con la incorporación de los necesarios paratextos "traductores" en la edición, si bien, suponemos, la obra no fue originalmente concebida para ser colocada en el mercado exterior. La crisis, la necesidad, terminó convirtiéndose en virtud.

El grotesco de las acciones de la mayoría de los episodios, queda sintetizado en la frase de la remera que lleva un personaje en el episodio "Los colores del campeón" (Jok): “Arriba los de abajo". A lo largo de los unitarios, vemos caer a un presidente de la Nación, a un gerente de YPF, a otro de un banco, y confundir a pobladores de un barrio vecino con saqueadores, vemos cuerpos y dignidades derruidas por el hambre, la carencia, la explotación económica. El recurso al grotesco, la sobrecarga de referencias al contexto social y político argentino, y el estilo de "realidadficción" que presenta historias de gente común en espacios concretos y cotidianos, son claves para historizar la violencia, situarla en una geografía y un período histórico, una Latinoamérica arrasada por el neoliberalismo que aún hoy sigue arrasando. Esas maneras de representar un "trauma social" 23 obtura la posibilidad de interpretar los relatos como posibles de acontecer en cualquier momento y en cualquier lugar.

\section{Bibliografía}

BERONE, L. (2012). "Historieta, discurso político y narración. La revista Fierro, entre dos épocas”, en L. Berone F. y Reggiani (eds.). Creencias bien fundadas: Historieta politica en Argentina, de la transición democrática al kircnerismo. Córdoba: Colección Estudios y Crítica de la Historieta Argentina, Universidad Nacional de Córdoba.

BERONE, L. y REGGIANI, F. (comps.). (2012). Creencias bien fundadas: Historieta politica en Argentina, de la transición democrática al kirchnerismo (Berone y Reggiani -eds-). Córdoba: Colección Estudios y Crítica de la Historieta Argentina, Universidad Nacional de Córdoba. 
-- (2014). Siete intentos de escritura sobre Héctor Oesterbeld: géneros, intertextos y temas de la bistorieta argentina clásica. Córdoba: Colección Estudios y Crítica de la Historieta Argentina, Universidad Nacional de Córdoba.

BOITO, M. E. y ESPOZ, M. B. (comps.). (2014). Urbanismo estratégico y separación clasista. Instantáneas de la ciudad en conflicto. Rosario: Ed. Puño y Letra.

BOURDIEU, P. (1995). Las reglas del arte. Génesis y estructura del campo literario. Barcelona: Anagrama.

-- (2010). El sentido social del gusto. Elementos para una sociología de la cultura. Buenos Aires: Siglo XXI Editores.

HADJINICOLAOU, N. (1988). Historia del arte y lucha de clases. México: Siglo XXI.

Hernández, J. (1975). El gaucho Martín Fierro y La vuelta de Martín Fierro. Buenos Aires: Torres Agüero Editor.

LOSCHI, A. (2000). "El humor - Lo cómico - La risa”, en La Peste de Tebas, año 3, n¹5. Pp. 1423. Buenos Aires: Ed. La Peste.

LUDMER, J. (2006). “Literaturas posautónomas", en Ciberletras. Revista de crítica literaria y de cultura. Recuperado de: http://www.lehman.edu/ciberletras/v17/ludmer.htm. Accedido el 21 de febrero de 2016.

MARTÍN-BARBERO, J. (1987). De los medios a las mediaciones: Comunicación, cultura y hegemonía. Barcelona: Editorial Gustavo Gili.

MASOTTA, O. (1970). La bistorieta en el mundo moderno. Buenos Aires: Paidós.

MOSQUITO et al (eds.). Carne Argentina. Buenos Aires: La Productora.

NICASTRO, S. (2006). Revisitar la mirada sobre la escuela. Santa Fe: Homo Sapiens Ediciones.

PEPPINO BARALE, A. M. (2012). Narrativa Gráfica. Los entresijos de la historieta, México: Universidad Autónoma Metropolitana.

REGGIANI, F. (2008) "De la revista al libro: La edición de historietas argentinas después del 2001". III Foro de Investigación e Intervención Social. Córdoba, 24 y 25 de noviembre de 2008: Escuela de Ciencias de la Información. Universidad Nacional de Córdoba. Recuperado de: http://historietasargentinas.wordpress.com/2008/12/09/delarevistaallibrolaediciondehistorietas argentinasdespuesfedericoreggiani/. Accedido el 30 de marzo de 2016. 
-- (2010). “¿Quién 'dice' una historieta?: Historietas y teoría de la enunciación, un resumen”. Primer Congreso Internacional de Historietas Viñetas Serias, 23 al 25 de septiembre de 2010. Buenos Aires: Biblioteca Nacional. Recuperado de: http://www.vinetassueltas.com.ar/congreso/pdf/HistorietaLenguajeyRepresentacion/reggiani.pdf. Accedido el 30 de marzo de 2016.

-- (2012a). "Nombres propios, política y representación: Sarna y El síndrome Guastavino", en Creencias bien fundadas: Historieta politica en Argentina, de la transición democrática al kirchnerismo (Berone y Reggiani -eds-). Córdoba: Colección Estudios y Crítica de la Historieta Argentina, Universidad Nacional de Córdoba.

-- (2012b). "Historietas, autobiografía y enunciación: las increíbles aventuras del yo", en A. M. Peppino Barale (coord.) Narrativa Gráfica. Los entresijos de la bistorieta, México: Universidad Autónoma Metropolitana, pp. 105-119.

VERÓN, E. (1993). La Semiosis Social. Fragmentos de una teoría de la discursividad. Barcelona: Gedisa Editorial.

VIGNA, D. (2014a). La década posteada. Blog de escritores argentinos (2002-2012). Córdoba, Argentina: Alción Editora.

-- (2014b). "Discusiones en torno a la tensión literatura-mercado en la Argentina de la última década. Los nuevos formatos de publicación web”. En Aposta - Revista de Ciencias Sociales, n 60. Recuperado de: http://www.apostadigital.com/revistav3/hemeroteca/vigna1.pdf. Accedido el 25 de marzo de 2016.

VOLOSHINOV, V. (1992). El marxismo y la filosofía del lenguaje (Los principales problemas del método sociológico en la ciencia del lenguaje). Madrid: Alianza.

VON SPRECHER, R. (1996). Arte desde los géneros y medios de comunicación masivos en Argentina: modelos de sociedad y de agentes sociales en «El Eternauta» y en «Mort Cinder» de Héctor Germán Oesterbeld. Informe de Investigación para el Fondo Nacional de las Artes, Mimeo, Córdoba.

-- (2009). "Desarrollo del campo de la historieta argentina. Entre la dependencia y la autonomía". En Diálogos de la Comunicación, revista académica de la Federación Latinoamericana de Facultades de Comunicación Social (FELAFACS), nº 78.

-- (2010). "Luchas en el campo de la historieta argentina. Civiles y militares en obras de Robin Wood y de Héctor Germán Oesterheld". En Estudios y Crítica de la Historieta Argentina. 
http://historietasargentinas.files.wordpress.com/2010/02/vonsprecher robinwood.pdf.

Accedido el 2 de abril de 2016.

WILLIAMS, R. (1981). Cultura. Sociología de la comunicación y del arte. Barcelona: Paidós.

ŽIŽEK, S. (comp.) (2003). Ideología. Un mapa de la cuestión. Buenos Aires: Fondo de Cultura Económica.

\section{Apéndice de imágenes}

Aclaración: las imágenes son ilustrativas, sin constituir referencias a todas las secuencias de la historieta que han sido comentadas en el análisis de la obra, en la sección "3. Resultados".
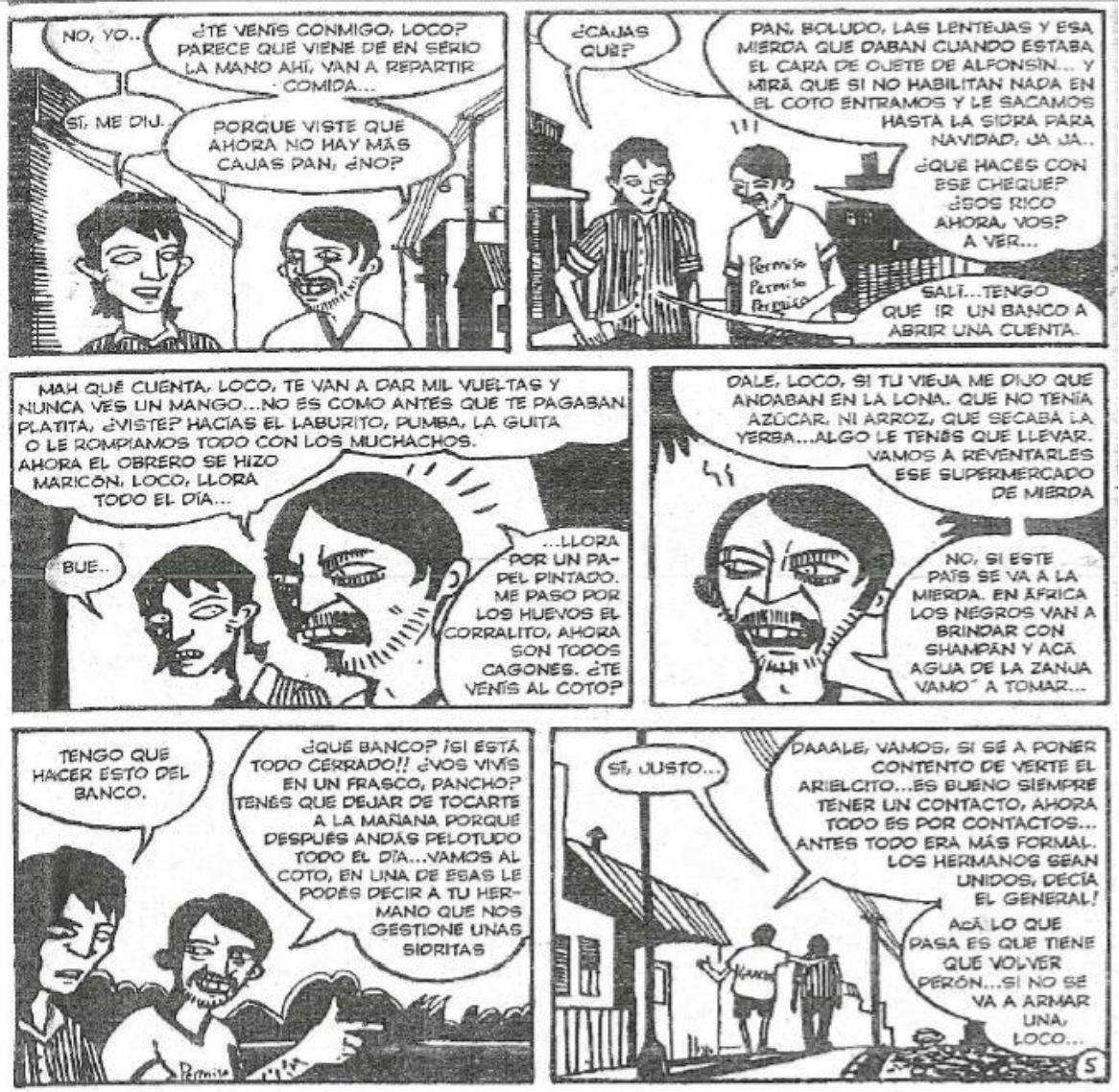

Fig. 1: Historieta "Los devoran los de afuera", de Mosquito. En la secuencia, un diálogo entre

"Pancho" y su vecino, el "Flaco". 

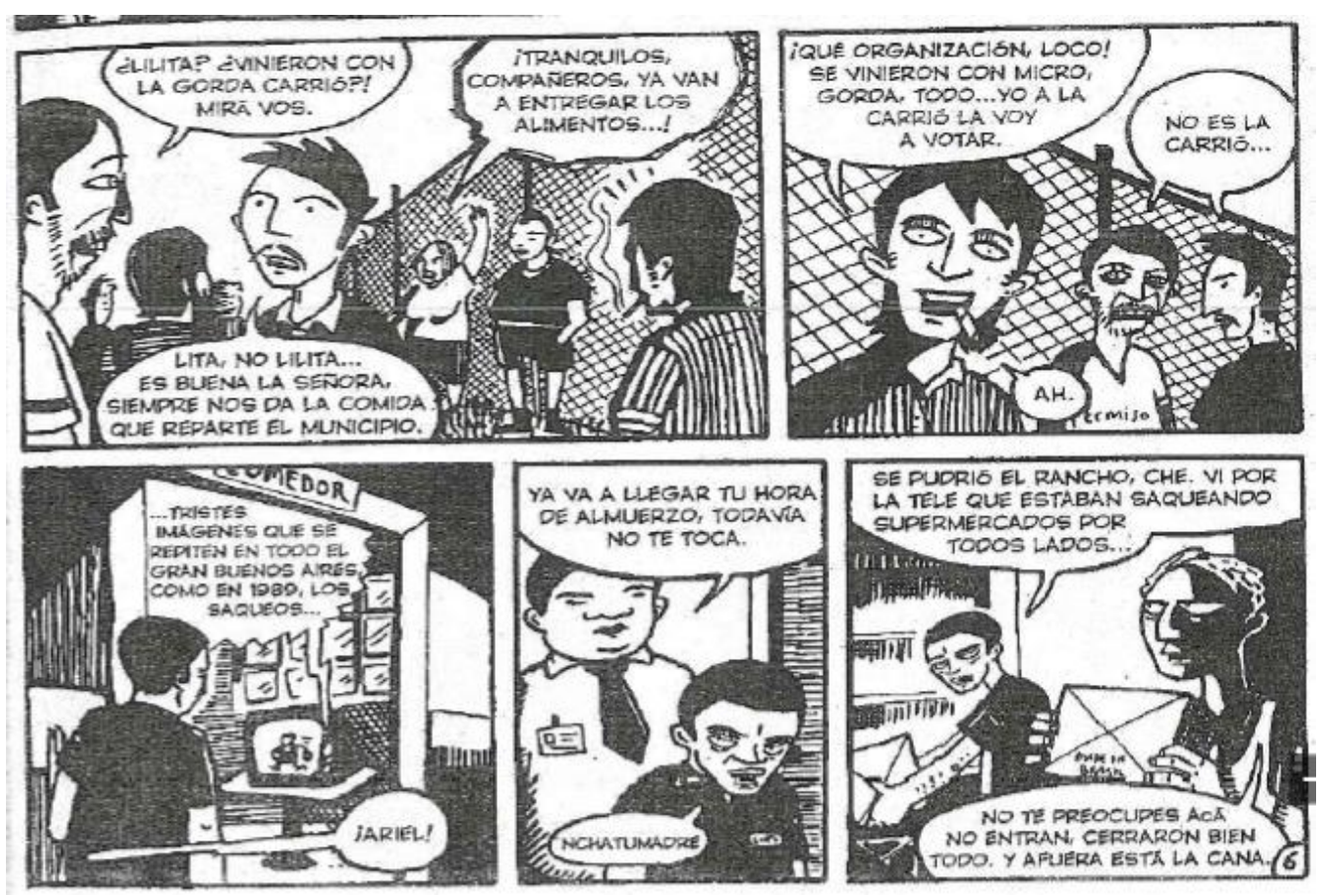

Fig. 2: Historieta "Los devoran los de afuera", de Mosquito.
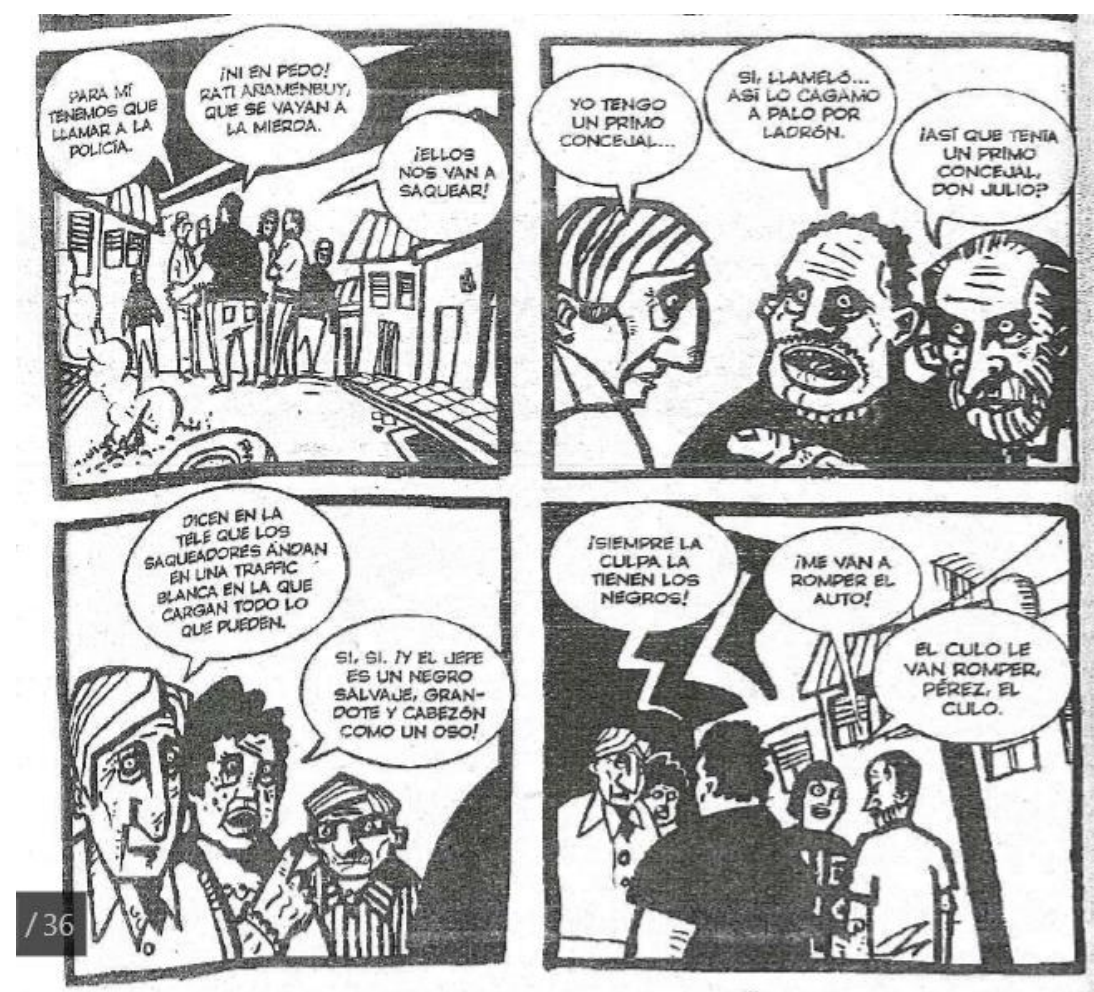

Figura 3: "Los inadaptados de siempre", unitario de Cristian Mallea y Aón. 

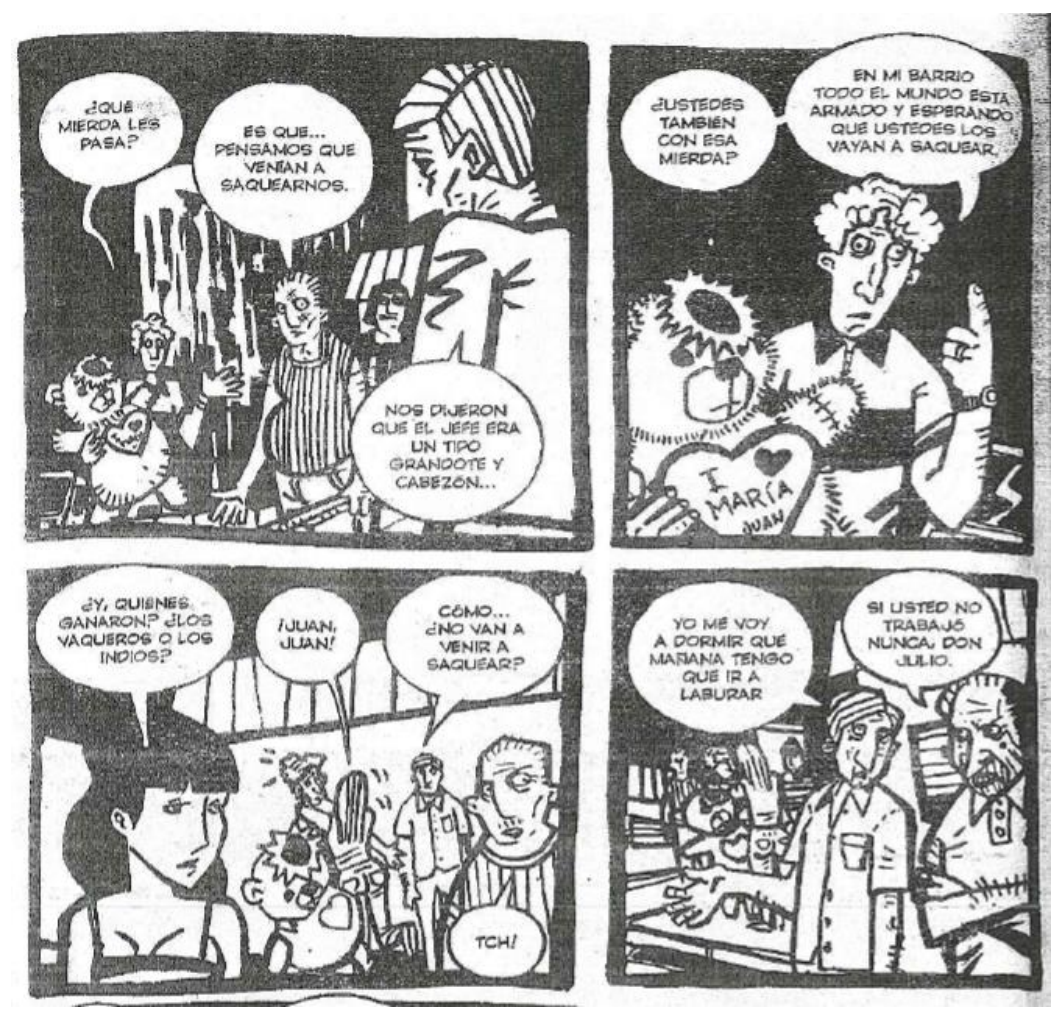

Figura 4: "Los inadaptados de siempre" (Cristian Mallea y Aón).

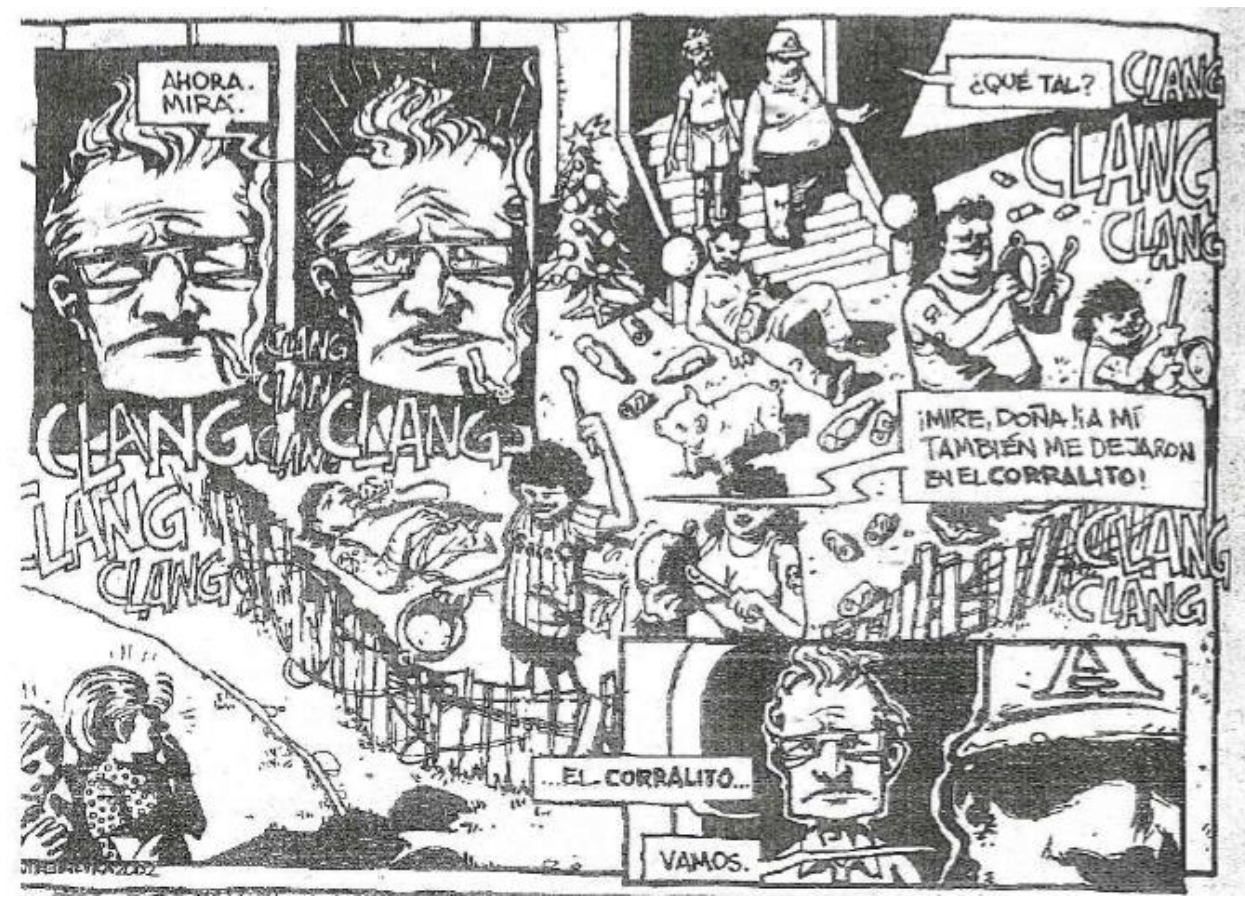

Figura 5: "Uno de los pibes" (Diego Agrimbau y Dante Ginevra). 


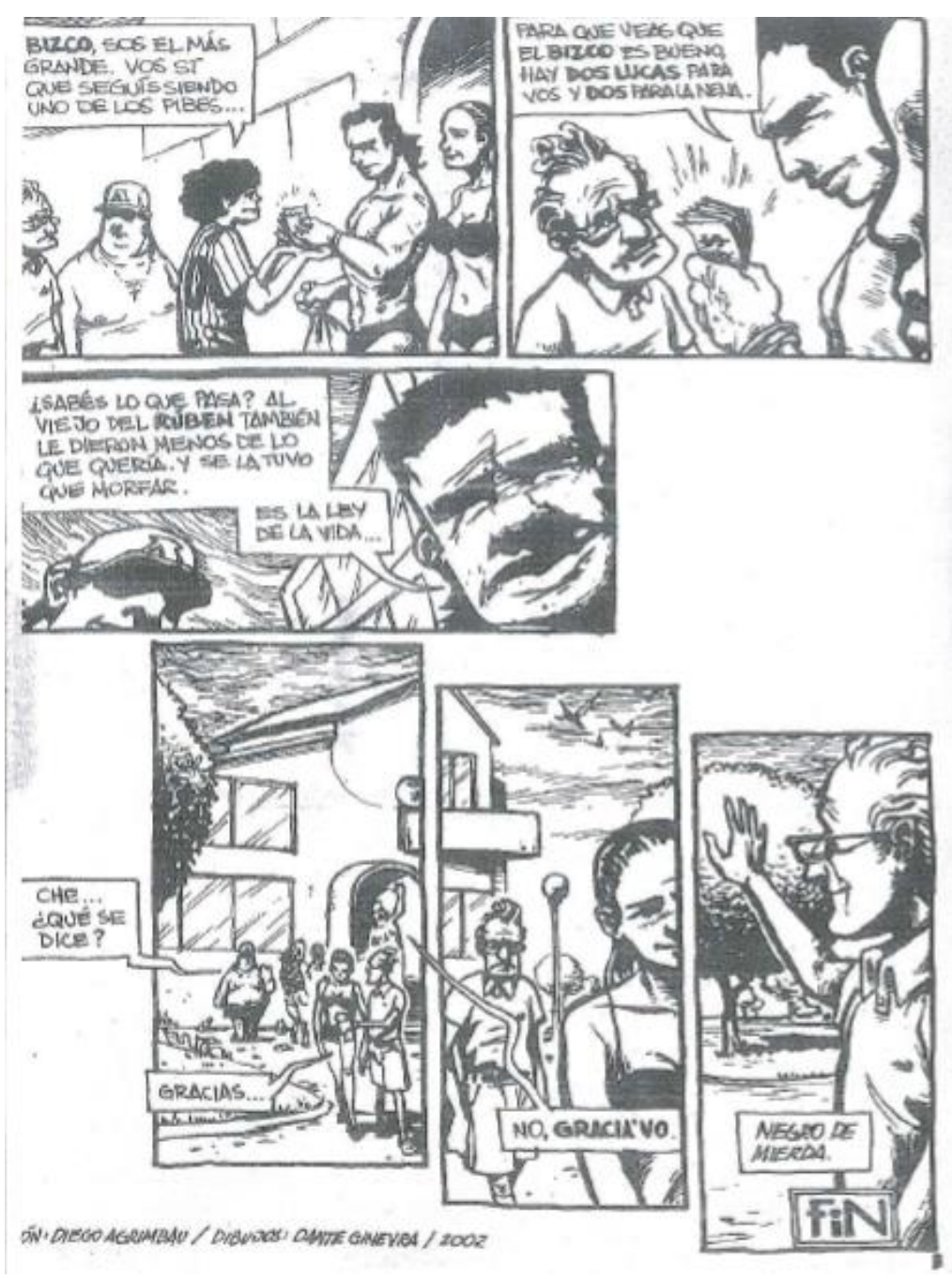

Figura 6: "Uno de los pibes" (Diego Agrimbau y Dante Ginevra). 

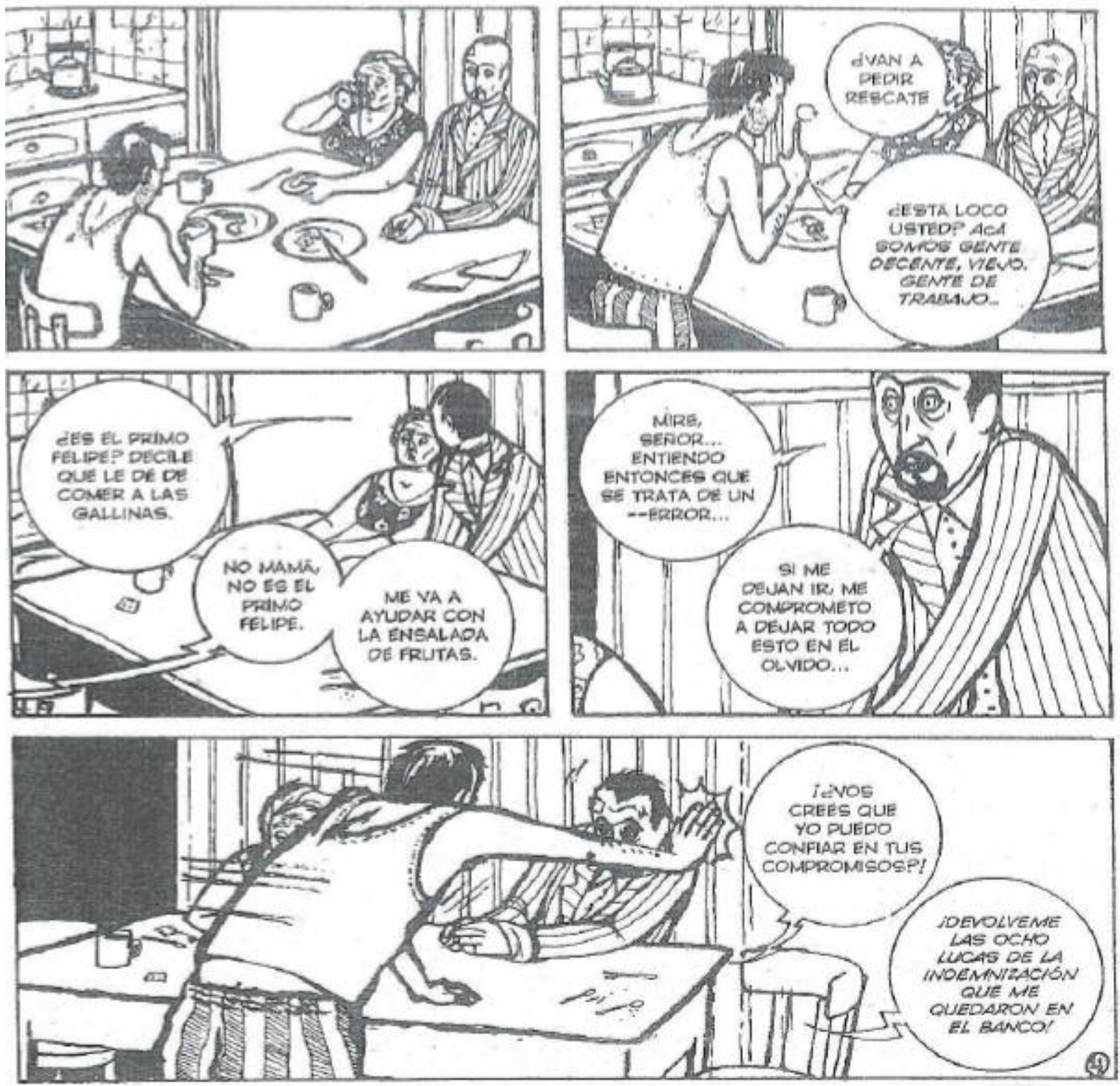

Figura 7: "El corralito”, de Federico Reggiani y Gervasio. 

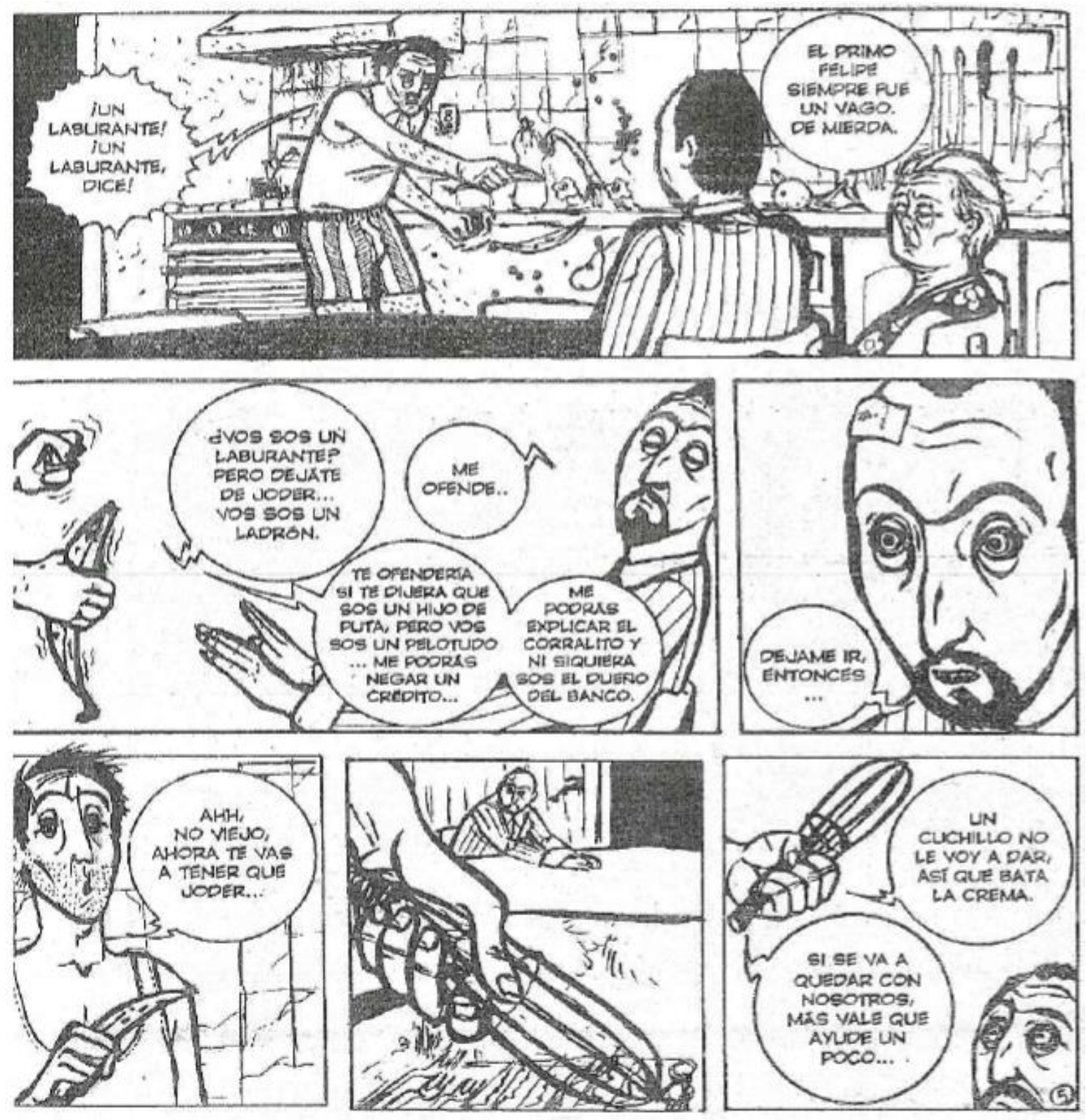

Figura 8: "El corralito" (Federico Reggiani y Gervasio).

\section{Notas}

${ }^{1}$ Este último sello, líder en ventas y popularidad durante décadas, tuvo una última década de agonía republicando material viejo de autores que ya hacía años trabajaban en y/o para el exterior o estaban insertos en otras actividades laborales, como las series del guionista Robin Wood.

${ }^{2}$ Comunicación personal del autor Diego Vigna.

3 No obstante, el modelo de producción seriada enmarcada en los géneros de aventuras tradicionales, comenzó a resquebrajarse en los años ochenta, de la mano de la revista Fierro. Este proyecto editorial se opuso a las grandes editoriales Columba y Ediciones Record, al plantear propuestas narrativas no tradicionales, optando por una mayor complejidad genérica, experimentación gráfica, y la decisión de publicar "historieta de autor". La renovación estética implicaría, asimismo, un posicionamiento político: la revisión histórica del pasado -plasmado en 
las series La Tripe B, Ficcionario y La Batalla de Malvinas- y la construcción de referentes de esa resistencia ideológica y política, como la figura de Héctor Germán Oesterheld.

${ }^{4}$ Denominamos de esta manera a la historieta para distinguirla del humor gráfico y sus parientes cercanos.

${ }^{5}$ La dirección web del blog es https://historietasreales.wordpress.com/. El texto de presentación que citamos a continuación, visible en la portada de la plataforma, da una idea al lector de su contenido: "El resultado es Historietas reales, un site en el que diariamente se pueden leer historias confesionales y bien de barrio, donde las novias de los dibujantes son protagonistas, así como sus hijos, sus trabajos y sus vacaciones. Un proyecto original y generoso, apasionante para cualquier fanático del género, al que no dejan de sumarse dibujantes. Y lectores".

${ }^{6}$ La historieta Veinte Verdades fue publicada en entregas unitarias en la revista Fierro, entre 2011 y 2012, aunque no llegó a los 20 episodios, que es precisamente la cantidad de "Verdades Peronistas" al que hace referencia el nombre de la serie.

7 Menemismo se denomina al período político de la historia argentina enmarcado por las dos presidencias de Carlos Saúl Menem (1989-1999). Menem, de origen peronista, terminó llevando adelante un Gobierno de derecha neoliberal -caracterizado por privatizaciones de empresas y servicios públicos, apertura del comercio exterior, flexibilización de leyes laborales en favor de la patronal empresaria, congelamiento de salarios, recortes presupuestarios en áreas de Salud, Educación y Desarrollo Social, y alineamiento político y económico con los Estados Unidos en materia de política exterior-. Estas políticas implicaron un drástico alejamiento de los postulados esenciales del programa político creado en los años cuarenta por el fundador del movimiento justicialista, Juan Domingo Perón.

${ }^{8}$ La referencia del título al célebre consejo del gaucho Martín Fierro a sus hijos, en La Vuelta de Martín Fierro, de José Hernández, es ineludible: "Los hermanos se han unido, porque esa es la ley primera; tengan unión verdadera en cualquier tiempo que sea, porque si entre ellos pelean los devoran los de ajuera".

9 El nombre ficticio de "Barrio Chorizo", suponemos, puede tener como referente a alguna barriada del conurbano bonaerense, hacer referencia a la influencia de la construcción italiana en las urbanizaciones argentinas, en particular de la ciudad de Buenos Aires y alrededores casitas bajas tipo chorizo: viviendas largas con habitaciones dispuestas en hilera cuyas puertas de acceso dan a un pasillo que las comunica.

${ }^{10}$ Las Cajas PAN (Programa Alimentario Nacional) eran una ayuda alimentaria que el Gobierno de Raúl Alfonsín (1983-1989) repartía entre los sectores más carenciados de la población argentina.

${ }^{11}$ El "Viejo Vizcacha" es un ser taimado, huraño y ventajero, la representación personificada de los antivalores del egoísmo, la avaricia, el cinismo y la picardía "criolla" en esta obra clásica de la literatura de habla hispana. Transcribimos la estrofa completa con la enseñanza del personaje tal como figura en La Vuelta del Martín Fierro:

"Hacete amigo del juez, no le des de qué quejarse y cuando quiera enojarse 
vos te tenés que encoger,

que siempre es bueno tener

palenque ande ir a rascarse."

12 Crónica es un periódico argentino, uno de los de mayor tirada y de público lector de origen popular, caracterizado por su sensacionalismo. El grupo Crónica cuenta además con un canal de televisión, Crónica TV, reconocido por sus placas noticiosas de corte amarillista.

13 La referencia es clara a un caso de fuerte repercusión pública en la Argentina que tuvo como hecho central a la ingesta de gatos en una villa de Rosario. La eficacia de la "anécdota" debe contar con la participación del lector avezado en la cultura -y en particular en la cultura mediática- argentina para completar el sentido. De hecho, ha quedado marcado en el folclore futbolero: no es raro que las hinchadas de clubes de fútbol, en especial porteños y cordobeses, apoden en sus cánticos a los equipos rosarinos y a sus seguidores con el epíteto de "come-gatos".

${ }^{14}$ En Argentina, probablemente el insulto racista más frecuente que puede dársele a una persona o a un grupo de personas es "negro de mierda". Las situaciones de uso son variadas, y el destinatario no responde a una identidad precisa, sino que la agresión depende del contexto y de la construcción identitaria que el agresor atribuya a un "otro". Para el común de los argentinos, que de hecho en algún momento de sus vidas han usado esta agresión verbal, el "negro de mierda" suele ser un "otro" de clase, que generalmente es una persona perteneciente a un estrato social o a un nivel cultural percibido como inferior respecto al detentado por quien insulta. La definición no sólo es una marca de diferenciación social, sino también racial. El "otro" es colocado por fuera del patrón fenotípico "normal" de la población argentina: ser blanco de ascendencia europea (claro que esto se trata de una construcción imaginaria, que poco tiene que ver con la composición étnica del citado país sudamericano). "Negro de mierda" define tanto al agredido como al agresor: el primero suele ser -y suele ser estigmatizado como- un pobre, o una persona que en términos étnicos, socioculturales y/o socioeconómicos presenta características y prácticas asociadas a la pobreza (por ejemplo, vive en un barrio humilde, cobra un subsidio de desempleo y escucha música del género cumbia), en tanto que del lado del agresor, tenemos a una persona que se identifica dentro de la "clase media" -aunque de hecho éste sea otro sujeto de condición social baja o sea percibido por los demás como tal- y se asume como culta, educada y blanca -si bien a su pertenencia racial autopercibida raramente la explicite-. Se trata, en fin, de una expresión verbal que remite como pocas al longevo conflicto entre "civilización" y "barbarie" existente en Argentina desde su constitución como nación.

15 "Grasa", en el castellano rioplatense, se utiliza para designar despectivamente algo o alguien al que se identifica con la clase baja o está fuera de moda, careciendo de toda elegancia. El término "grasa" no está lejos del típicamente argentino "negro de mierda", ambos componentes del léxico nacional que representa barreras de clase. Eva Perón usaba esa palabra invirtiendo el sentido de la misma, para interpelar sus "descamisados", aquellos primeros partidarios del primer Gobierno peronista (1946-1955), llamándolos con afecto "mis grasitas". No obstante, ese uso del calificativo por la esposa del General Juan D. Perón no acortaba la distancia de clase que connotaba, cuestión que tiene correlación con el modelo de sociedad defendido por el mismo peronismo: una sociedad capitalista, dividida en clases, con desarrollo industrial, un fuerte mercado interno y una distribución progresiva de la riqueza. 
${ }^{16}$ Entre los noventa y los primeros años del siglo XXI, en la Argentina los centros comerciales denominados "shoppings" eran lugares frecuentados por sectores de clase media y media-alta, al contrario de la tendencia de los últimos diez años, en que estos "no lugares" urbanos se han convertido, en buena medida, en espacios de esparcimiento de la clase media baja y de sectores populares, si bien eso depende de cada región de Argentina. Como práctica de distinción, buena parte de los sectores sociales acomodados ya no acuden a los shoppings ni al centro de la ciudad como espacios de compra, paseo o recreación. La tendencia de separación clasista (Boito y Espoz, 2013) consistente en evitar el encuentro con el "otro" de clase se ha acrecentado en el período abierto en Argentina desde 2003, que si bien significó una recuperación económica y productiva para el país, también implicó un aumento en la brecha de desigualdad social, económica y simbólica entre las clases sociales.

${ }^{17}$ El lugar de la ficción hace referencia a una precisa exterioridad social y geográfica, una ciudad de Argentina, y que se indica en la "ficha" de presentación del personaje.

18 Gatica, el Mono es una película argentina dirigida por Leonardo Favio, que relata la vida del boxeador José María Gatica, quien tuvo una reconocida simpatía por el Gobierno de Perón.

19 Unidad Básica se denomina en Argentina a los centros partidarios del Partido Justicialista, donde los militantes peronistas se reúnen para realizar distintas actividades. Suelen registrar mayor movimiento en tiempo de elecciones.

${ }^{20}$ Domingo Cavallo ya había sido ministro de Economía en las presidencias de Carlos Menem (1991-1996). Fue el mentor del plan Convertibilidad que establecía la paridad cambiaria entre peso y dólar, de las políticas de privatizaciones y de apertura comercial que favorecieron las importaciones y provocaron el desmantelamiento del aparato económico productivo de Argentina. Fue reconocido asimismo por sus recortes presupuestarios a las áreas de salud, previsión social, educación y desarrollo científico. Pasó a la posteridad su frase "vayan a lavar los platos", propinada a una investigadora del Consejo Nacional de Investigaciones Científicas y Técnicas de Argentina (Conicet), la socióloga Susana Torrado, quien reclamaba mejores condiciones laborales y salariales para los trabajadores científicos de la Argentina.

${ }^{21}$ Entre el 20 de diciembre de 2001 y el 2 de febrero del año siguiente, hubo en Argentina una seguidilla de cinco presidentes, que concluye con la asunción del peronista Eduardo Duhalde, a la sazón el candidato derrotado en las elecciones de 1999 por el fallido Fernando De la Rúa. Duhalde adelantó la entrega del mando a mayo de 2003 (con la asunción de Néstor Kirchner, vencedor en las elecciones presidenciales de ese año), a causa de la represión policial que se cobró la vida de dos militantes en medio de las protestas sociales contra el Gobierno interino desatadas en Avellaneda, a fines de junio de 2002.

22 Yacimientos Petrolíferos Fiscales (YPF) fue una de las empresas estatales de Argentina privatizadas durante la primera presidencia de Carlos Menem a comienzos de los años noventa.

${ }^{23}$ Laura Cristina Fernández (comunicación interna no publicada). 


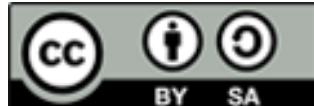

Licencia Creative Commons

Miguel Hernández Communication Journal

mhcj.es

Forma de citar este artículo en las bibliografías

Dr. Sebastian Horacio Gago (2016): "Carne Argentina: las representaciones de la crisis de 2001 en la historieta”, en Miguel Hernández Communication Journal, nº7, páginas 139 a 168.

Universidad Miguel Hernández, UMH (Elche-Alicante). Recuperado el _ de de

20__ de: Џink del artículo en mhjournal.org] 